\title{
Chill unit accumulation and necessity of rest breaking agents in South African table grape production regions
}

\author{
Eunice Avenant $^{1, \mathrm{a}}$ and Jan Hendrik Avenant ${ }^{2}$ \\ ${ }^{1}$ South African Table Grape Industry, PO Box 2932, Paarl 7620, South Africa \\ ${ }^{2}$ ARC Infruitec-Nietvoorbij (The Fruit, Vine and Wine Institute of the Agricultural Research Council), Private Bag \\ X5026, Stellenbosch 7599, South Africa
}

\begin{abstract}
Cultivation of table grapes in warm regions of South Africa is complicated by problems associated with delayed and uneven bud break. Rest breaking agents, mainly hydrogen cyanamide, are applied to overcome these problems. The chill unit accumulation of the five major table grape production regions in South Africa was compared with the minimum chilling required to obtain a high bud break percentage $(>80 \%)$ and even bud break, defined as 200 hours between 0 and $10^{\circ} \mathrm{C}$, or 400 hours at $3^{\circ} \mathrm{C}$. The effect of chilling accumulation $(0,50,100$, 200,400 and 800 hours at $3^{\circ} \mathrm{C}$ ) on bud break of dormant cuttings of three table grape cultivars was investigated in controlled studies in a glass house over a three year period. Cuttings used in the study were collected from commercial vineyards in Saron in the Berg River Valley (representing a warm region) and the Hex River Valley (representing a cool region). Sultanina and Sugraone cuttings from Saron required at least 200 hours at $3{ }^{\circ} \mathrm{C}$ to obtain a final bud break \% of $80 \%+$. A final bud break \% of $80 \%+$ was obtained with all Sultanina cuttings from Hex River Valley. Treatments receiving 400 and 800 hours at $3^{\circ} \mathrm{C}$, showed the most rapid rate of bud break. Prime cuttings collected from Saron, receiving 0,50, 100 and 400 hours at $3{ }^{\circ} \mathrm{C}$, showed a more rapid bud break process, as well as a higher final bud break \% compared to Sugraone and Sultanina. It seems as if Prime has a lower chilling requirement than the other two cultivars. The model of Dokoozlian for quantifying chilling status is applicable to Saron and the Hex River Valley. The necessity of using rest breaking chemicals in the Saron area, for obtaining a high bud break $\%$ and even bud break, was confirmed. The Hex River Valley receives sufficient chilling temperatures to obtain a high bud break \%, but rest breaking chemicals can be used to obtain more even bud break. The use of hydrogen cyanamide for improved and even bud break is a general practice in regions that receive less than 400 chill units. In regions receiving more than 400 chill units, several producers still use hydrogen cyanamide for even bud break. It is recommended that the chilling requirement of economic important cultivars should be determined simultaneously in field trials and glass house trials for the major table grape production regions of South Africa, to verify the necessity of using rest breaking chemicals for specific cultivars in specific regions.
\end{abstract}

\section{Introduction}

Cultivation of table grapes in warm regions of South Africa is complicated by problems associated with low, delayed and uneven bud break (decreased shoot and cluster counts per vine, uneven shoot and cluster development, decreased yield and quality). Rest breaking agents, mainly hydrogen cyanamide $\left(\mathrm{H}_{2} \mathrm{CN}_{2}\right)$, are applied to overcome these problems. This practice increase production costs in an industry where producers are already experiencing severe cost pressure.

Any manipulation should only be done if is it scientifically proven to be necessary, as well as economically justified. The minimum chilling required to obtain a high bud break percentage $(>80 \%)$ and even bud break in grapevines, was defined as 200 hours between 0 and $10{ }^{\circ} \mathrm{C}$, or 400 hours at $3{ }^{\circ} \mathrm{C}$ [1]. Results reported from previous studies indicated that when chilling exceed $400 \mathrm{~h}$ at $3{ }^{\circ} \mathrm{C}$, the response of grapevines to $\mathrm{H}_{2} \mathrm{CN}_{2}$ is greatly reduced [2] and that there is little benefit when $\mathrm{H}_{2} \mathrm{CN}_{2}$ is

\footnotetext{
${ }^{a}$ Corresponding author: eunice@satgi.co.za
}

applied to vines grown in regions accumulating sufficient chilling because the bud break of non-treated vines in these regions is sufficient [3].

The objectives of this study were to:

- Compare temperature and chill unit accumulation in the five major table grape regions;

- Verify the necessity of using rest breaking agents in the respective regions;

- Evaluate the effect of chilling accumulation on bud break of three table grape cultivars in two regions; and

- Evaluate the potential application of an existing model [4] for quantifying the chilling status of grapevines in two table grape regions.

\section{Materials and methods}

\subsection{Comparison of chill unit accumulation for five production regions}

The chill unit accumulation for each of the five major table grape production regions in South Africa (Hex 
River Valley, Orange River region, Berg River Valley, Olifants River Valley, Limpopo) was compared with the minimum chilling required to obtaiet aln a high bud break percentage ( $>80 \%)$ and even bud break, defined as 200 hours between 0 and $10^{\circ} \mathrm{C}$, or 400 hours at $3{ }^{\circ} \mathrm{C}$ [1].

Mean monthly, as well as long term temperature and chill unit data of the five major table grape production regions were obtained from the ARC Institute for Soil Climate and Water (ARC ISWC). Hourly temperature data for Saron and the Hex River Valley Experimental Farm were also obtained from the ARC ISCW for weather stations at Porterville (10 km from Saron) and the Hex River Valley Experiment Farm respectively. Long term monthly average chill unit accumulation is presented for May to August, as well as the total chill unit accumulation of this 4 month period. Chill unit accumulation is presented as Utah cold units (CU) calculated according to the model of Richardson et al. [5] as well as daily positive chilling units (DPCU) according to the model of Linsley-Noakes et al. [6].

\subsection{Glasshouse trial}

The effect of chilling accumulation (0, 50, 100, 200, 400 and 800 hours at $3{ }^{\circ} \mathrm{C}$ ) on bud break of dormant cuttings of three table grape cultivars was investigated in controlled studies in a glass house over a three year period (2004, 2005 and 2006).

Cuttings used in the study were prepared from dormant shoots representative of typical canes, collected from commercial vineyards in Saron in the Berg River Valley, representing a warm region (Sultanina, Prime, Sugraone) and the Hex River Valley, representing a cool region (Sultanina). Chilling status of grapevines in the two regions was determined according to the Coachella model of Dokoozlian [3].

The collected dormant shoots were immersed in water, containing a fungicide (captab $500 \mathrm{~g} / \mathrm{L}$ ), drained for several minutes and placed in sealed plastic bags, which were stored in darkness at $3{ }^{\circ} \mathrm{C}$ for $50,100,200,400$ and $800 \mathrm{~h}$. A non-chilled control was included in the experiment. After chilling treatments were completed, the single node cuttings were prepared and placed in water trays in a glasshouse, at forcing temperature $\left(22^{\circ} \mathrm{C}\right)$. Cuttings were monitored for bud break three times per week. Bud break date was defined as the first day that green tissue beneath the bud scales was observed. The experimental design was a fully randomised block design, with eight replications of ten single node cuttings per experimental unit.

Data presented include the effect of chilling treatment on cumulative bud break for each cultivar, a comparison of temperature and chilling status between the two regions, as well as chilling requirements of the three table grape cultivars included in the trial. Similar trends were found in all three seasons. Data of 2004 and 2006 are presented.

\section{Results and discussion}

\subsection{Temperature and chill unit accumulation of the five major table grape production regions}

Long term mean chill unit accumulation of the five major table grape production regions in South Africa is presented
Table 1. Long term mean chill unit accumulation in the five major table grape production regions in South Africa.

\begin{tabular}{|c|c|c|c|c|}
\hline $\begin{array}{l}\text { Region and weather } \\
\text { station }\end{array}$ & $\begin{array}{l}\text { Data } \\
\text { period }\end{array}$ & Month & $\overline{\mathbf{C U}}$ & DPCU \\
\hline \multicolumn{5}{|c|}{ Hex River Valley } \\
\hline \multirow{5}{*}{$\begin{array}{l}\text { Hex River Valley } \\
\text { Experiment Farm } \\
\left(33^{\circ} 47^{\prime} \mathrm{S}, 19^{\circ} 67^{\prime} \mathrm{E} \text {, }\right. \\
\text { Alt. } 457 \mathrm{~m})\end{array}$} & \multirow{5}{*}{ 2004-2012 } & 5 & 44 & 129 \\
\hline & & 6 & 202 & 230 \\
\hline & & 7 & 240 & 265 \\
\hline & & 8 & 195 & 220 \\
\hline & & Total & 681 & 843 \\
\hline \multicolumn{5}{|c|}{$\begin{array}{c}\text { Orange River Region } \\
\end{array}$} \\
\hline \multirow{5}{*}{$\begin{array}{l}\text { Kakamas } \\
\left(28^{\circ} 79^{\prime} \mathrm{S}, 20^{\circ} 66^{\prime} \mathrm{E} \text {, }\right. \\
\text { Alt. } 662 \mathrm{~m})\end{array}$} & \multirow{5}{*}{ 1996-2012 } & 5 & -119 & 50 \\
\hline & & 6 & 52 & 112 \\
\hline & & 7 & 39 & 108 \\
\hline & & 8 & -49 & 79 \\
\hline & & Total & -78 & 349 \\
\hline \multirow{5}{*}{$\begin{array}{l}\text { Augrabies } \\
\left(28^{\circ} 64^{\prime} \mathrm{S}, 20^{\circ} 35^{\prime} \mathrm{E},\right. \\
\text { Alt. } 648 \mathrm{~m})\end{array}$} & \multirow{5}{*}{$1997-2012$} & 5 & -146 & 44 \\
\hline & & 6 & 77 & 128 \\
\hline & & 7 & 75 & 125 \\
\hline & & 8 & -24 & 94 \\
\hline & & Total & -18 & 391 \\
\hline \multicolumn{5}{|c|}{ Berg River Valley } \\
\hline \multirow{5}{*}{$\begin{array}{l}\text { Paarl (Bellevue) } \\
\left(33^{\circ} 74^{\prime} \mathrm{S}, 18^{\circ} 96^{\prime} \mathrm{E},\right. \\
\text { Alt. } 158 \mathrm{~m})\end{array}$} & \multirow{5}{*}{ 2005-2012 } & 5 & -69 & 66 \\
\hline & & 6 & 119 & 162 \\
\hline & & 7 & 161 & 194 \\
\hline & & 8 & 166 & 203 \\
\hline & & Total & 377 & 625 \\
\hline \multirow{5}{*}{$\begin{array}{l}\text { Porterville } \\
\left(33^{\circ} 16^{\prime} \mathrm{S}, 19^{\circ} 03^{\prime} \mathrm{E} \text {, }\right. \\
\text { Alt. } 126 \mathrm{~m})\end{array}$} & \multirow{5}{*}{ 2007-2012 } & 5 & -212 & 36 \\
\hline & & 6 & 8 & 103 \\
\hline & & 7 & 74 & 163 \\
\hline & & 8 & 56 & 133 \\
\hline & & Total & -74 & 436 \\
\hline \multicolumn{5}{|c|}{ Olifants River Valley } \\
\hline \multirow{5}{*}{$\begin{array}{l}\text { Vredendal } \\
\left(31^{\circ} 69^{\prime} \mathrm{S}, 18^{\circ} 48^{\prime} \mathrm{E} \text {, }\right. \\
\text { Alt. } 43 \mathrm{~m})\end{array}$} & \multirow{5}{*}{ 2004-2012 } & 5 & -89 & 48 \\
\hline & & 6 & 9 & 117 \\
\hline & & 7 & 98 & 148 \\
\hline & & 8 & 135 & 167 \\
\hline & & Total & 152 & 479 \\
\hline \multicolumn{5}{|c|}{ Limpopo } \\
\hline \multirow{5}{*}{$\begin{array}{l}\text { Groblersdal } \\
\left(25^{\circ} 17^{\prime} \mathrm{S}, 29^{\circ} 36^{\prime} \mathrm{E},\right. \\
\text { Alt. } 948 \mathrm{~m})\end{array}$} & \multirow{5}{*}{$1997-2012$} & 5 & -90 & 37 \\
\hline & & 6 & 92 & 114 \\
\hline & & 7 & 110 & 120 \\
\hline & & 8 & -64 & 45 \\
\hline & & Total & 48 & 316 \\
\hline
\end{tabular}

$\mathrm{CU}=$ Average total Utah cold units.

$\mathrm{DPCU}=$ Average total daily positive chilling units.

Alt $=$ Altitude.

in Table 1. The negative CU values for some months are ascribed to high daytime temperatures.

Compared to the minimum chilling required to obtain a high bud break percentage ( $>80 \%$ ) and even bud break, defined as 200 hours between 0 and $10^{\circ} \mathrm{C}$, or 400 hours at $3{ }^{\circ} \mathrm{C}$ [1], the .Hex River Valley and Berg River Valley (Paarl) have sufficient chill unit accumulation to obtain a high bud break percentage, while lower bud break percentages and delayed bud break are expected in the 


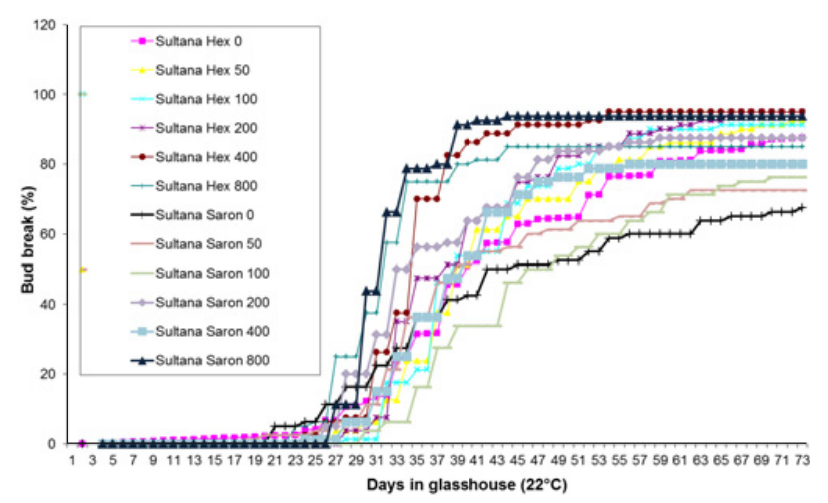

Figure 1a. Bud break \% of single-node Sultanina cuttings ollected from Saron and Hex River Valley (2004).

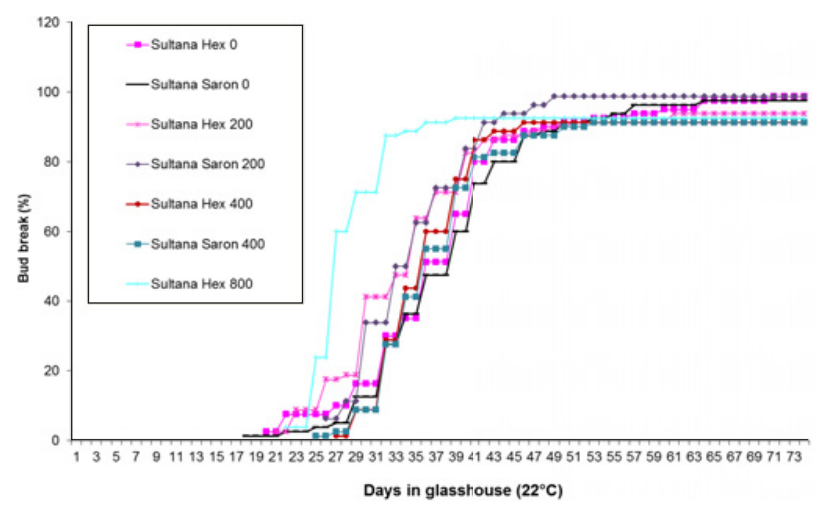

Figure 1b. Bud break \% of single-node Sultanina cuttings collected from Saron and Hex River Valley (2006).

Lower Orange River Region, the Saron/Porterville area of the Berg River Valley and Limpopo.

The use of hydrogen cyanamide for improved and even bud break is a general practice in areas that receive less than 400 chill units (Orange River Region, Olifants River Valley, the Saron area of the Berg River Valley, Limpopo). Although the Paarl area of the Berg River Valley and the Hex River Valley receive more than 400 chill units, several producers still use hydrogen cyanamide for even bud break. Further evaluation of the chilling requirement of economically important cultivars in the major table grape regions is recommended, to obtain cultivar specific scientific evidence regarding necessity of using rest breaking agents.

\subsection{Effect of chill unit accumulation on bud break of three table grape cultivars in two regions}

In Figs. $1 \mathrm{a}$ and $1 \mathrm{~b}$ the effect of chilling treatment on cumulative bud break of Sultanina cuttings from Saron and the Hex River Valley is presented for the 2004 and 2006 seasons respectively.

Delayed bud break, as well as a lower bud break \% $(<80 \%)$ was obtained with Sultanina cuttings from Saron, receiving 0,50 and 100 hours at $3{ }^{\circ} \mathrm{C}$, while a final bud break $\%$ of $80 \%+$ was obtained with cuttings receiving

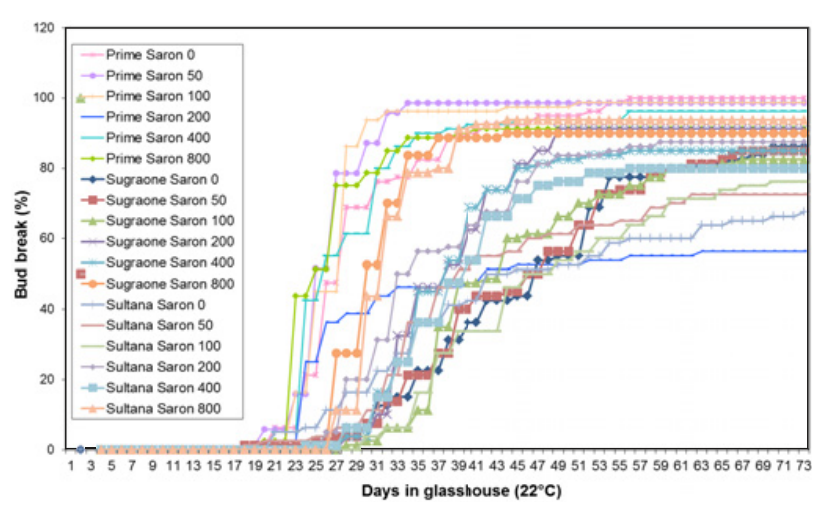

Figure 2a. Bud break \% of single-node cuttings of three table grape cultivars collected from Saron (2004).

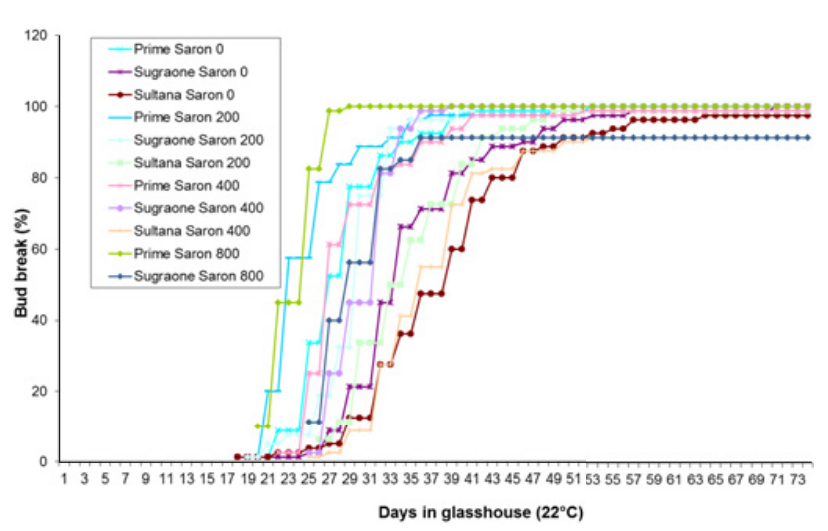

Figure 2 b. Bud break \% of single-node cuttings of three table grape cultivars collected from Saron (2006).

200, 400 and 800 hours at $3{ }^{\circ} \mathrm{C}$. A final bud break \% of $80 \%+$ was obtained with all Sultanina cuttings from Hex River Valley, which are ascribed to sufficient chilling temperatures received in the area.

The treatments receiving 400 and 800 hours at $3{ }^{\circ} \mathrm{C}$, showed the most rapid rate of bud break, which corresponds to the results of Dokoozlian [1].

In Figs. $2 a$ and $2 b$ the effect of chilling treatment on cumulative bud break of single-node cuttings of three table grape cultivars collected from Saron and the Hex River Valley is presented for the 2004 and 2006 seasons respectively.

Sugraone cuttings collected from Saron, receiving 0, 50 and 100 hours at $3{ }^{\circ} \mathrm{C}$, showed delayed bud break, however a final bud break of $80 \%+$ was obtained. Prime cuttings collected from Saron, receiving 0, 50, 100 and 400 hours at $3{ }^{\circ} \mathrm{C}$, showed a more rapid bud break process, as well as a higher final bud break \% compared to Sugraone and Sultanina. It seems as if Prime has a lower chilling requirement than the other two cultivars.

\subsection{Potential application of the Coachella model for quantifying chilling status of grapevines in two regions}

Chilling status for the two regions (Table 2) was determined according to the Coachella model of 
Table 2. Chilling status of grapevines in the Hex River Valley and Saron (2004 and 2006 seasons).

\begin{tabular}{|l|l|l|l|}
\hline \hline Site & $\begin{array}{l}\text { Chilling status } \\
\text { (Dokoozlian, 1998) }\end{array}$ & $\mathbf{2 0 0 4}$ & $\mathbf{2 0 0 6}$ \\
\hline $\begin{array}{l}\text { Hex River Valley } \\
\text { Experimental Farm } \\
\left(33^{\circ} 47^{\prime} 8,19^{\circ} 66^{\prime} \mathrm{E},\right.\end{array}$ & $\frac{\left.\text { Chilling temp (hours }<7^{\circ} \mathrm{C}\right)}{\left.\text { Chill negating temp (hours } \geq 20^{\circ} \mathrm{C}\right)}$ & 1.1 & 1.5 \\
$456 \mathrm{~m})$ & & & \\
\hline $\begin{array}{l}\text { Saron } \\
\left(33^{\circ} 01^{\prime} \mathrm{S}, 18^{\circ} 99^{\prime} \mathrm{E},\right. \\
149 \mathrm{~m})\end{array}$ & $\frac{\left.\text { Chilling temp (hours }<7^{\circ} \mathrm{C}\right)}{\left.\text { Chill negating temp (hours } \geq 20^{\circ} \mathrm{C}\right)}$ & 0.5 & 0.5 \\
\hline
\end{tabular}

Dokoozlian [3] by calculating the ratio between exposure to chilling temperatures (hours $<7^{\circ} \mathrm{C}$ ) and chill negating temperatures (hours $>20^{\circ} \mathrm{C}$ ) from 1 May to 6 June (date of sampling the cuttings). According to this model, delayed bud break and reduced total bud break is expected with a chill to chill negation ratio $<0.5$, while rapid and complete bud break is expected with a chill to chill negation ratio $>2$.

According to the Coachella model and the chilling status calculated for grapevines in the two regions, delayed bud break and a lower bud break \% were expected for Saron, compared to Hex River Valley.

Based on the results obtained with the glasshouse trial, the necessity of using rest breaking chemicals in the Saron area, for obtaining a high bud break $\%$ and even bud break, was confirmed Sultanina and Sugraone. The Hex River Valley receives sufficient chilling temperatures to obtain a high bud break \%, but rest breaking chemicals can be used to obtain more even bud break. The Coachella model of Dokoozlian for quantifying chilling status is thus applicable to Saron and the Hex River Valley.

\section{Conclusions}

It is recommended that the chilling requirement of economic important cultivars should be determined simultaneously in field trials and glass house trials for the major table grape production regions of South Africa, to verify the necessity of using rest breaking chemicals for specific cultivars in specific regions.

The Coachella model of Dokoozlian [4] for quantifying chilling status of grapevines should be evaluated further for other table grape productions regions in South Africa. It can be used as a decision making tool in planning of dormancy management practices.

Farms in Saron and Hex River Valley where material were collected: Kosie van Niekerk Boerdery (Abrie Nortje en Kobus Bothma); ARC Infruitec-Nietvoorbij (Hex Valley Experimental Farm).

Technical support provided by Tom Stevens of ARC Infruitec-Nietvoorbij (Viticulture) and Pieter Miller of the Department of Agriculture, Western Cape (Pomology).

Funding and facilities: Department of Agriculture, Western Cape; ARC Infruitec-Nietvoorbij.

\section{References}

[1] Dokoozlian, N.K., 1999. Chilling Temperature and Duration Interact on the Budbreak of 'Perlette' Grapevine Cuttings. HortScience 34(6), 1054-1056

[2] Dokoozlian, N.L. \& Willliams, L.E., 1995. Chilling exposure and Hydrogen Cayanhamied Interact in Breaking Dormancy of Grape Buds. HortScience 30(6): 1244-1247

[3] Williams, L.E., 1987. The effect of cyanamide on budbreak and vine development of Thompson Seedless grapevines in the San Joaquin Valley of California. Vitis 26: 107-113

[4] Dokoozlian, N.K., 1998. Quantifying the Chilling Status of Grapevines and the Response to Dormancybreaking Chemicals in the Coachella Valley of California. HortScience 33(3), 510

[5] Richardson, E.A., Seeley, S.D., Walker, D.R., 1974. A model for estimating the completion of rest for Redhaven and Elberta peach trees. HortScience 82, 302-306

[6] Linsley-Noakes, G.C., Allan, P. \& Matthee, G., 1994. Modification of rest breaking completion prediction models fro imporved accuarcyin South African stone fruit orchards. J.S. Afr. Hort. Sci. 4(1), 13-15 